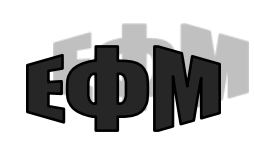

http://efm.vsau.org/

КОЗАЧЕНКО Анна Юріївна - кандидат економічних наук, старший викладач кафедри аудиту та державного контролю, Вінницький національний аграрний університет $(21008$, м. Вінниця, вул. Сонячна, 3, e-mail: sergeykozachenko@ukr.net).

ЧУДАК Ліна Анатоліївна, кандидат економічних наук, старший викладач кафедри аудиту та державного контролю Вінницький національний аграрний університет (21008, м. Вінниця, пров.Затишний, 5A, e-mail: chudaklina@ rambler.ru)

ЯРЕМЧУК Наталя Федорівна - кандидат економічних наук, старший викладач кафедри бухгалтерського обліку, Вінницький національний аграрний університет (21008, м. Вінниця, вул. Сонячна, 3, e-mail: yaremchuk7@i.ua).

КОЗАЧЕНКО Анна Юрьевна - кандидат экономических наук, старший преподаватель кафедры аудита и государственного контроля, Винницкий национальный аграрный университет (21008, г. Винница, ул. Солнечная, 3, e-mail: sergeykozachenko@ukr.net).

ЧУДАК Лина Анатольевна, кандидат экономических наук, старший преподаватель кафедры аудита и государственного контроля, Винницкий национальный аграрный университет (21008, г. Вінница, переул.Затышный, 5A, e-mail: chudaklina@ rambler.ru)

ЯРЕМЧУК Наталья Федоровна - кандидат экономических наук, старший преподаватель кафедры бухгалтерского учета, Винницкий национальный аграрный университет (21008, г.Винница, Солнечная, 3, e-mail: yaremchuk7@i.ua).

\section{ПОВЕАІНКА СПОЖИВАЧА В СУЧАСНІЙ РИНКОВІЙ ЕКОНОМІЦІ ${ }^{\circ}$}

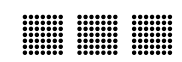

УДК 658.818:33.012.23 $\mid$
A. А. БРОЯКА, кандидат економічних наук, доцент, доцент кафедри економіки, Вінницький національний аграрний університет (м. Вінниця))

У статті досліджено особливості поведінки споживача в сучасних ринкових умовах. Висвітлено теоретично-методологічні підходи до формування споживачької поведінки та визначено екзогенні та ендогенні чинники, щзо на неї впливають. Окреслено різні моделі поведінки споживачів залежно від рівня їхнього доходу. Проаналізовано рівень та динаміку доходів населення України, в тому числі в міській та сільській місиевості. Досліджено динаміку витрат украӥнських споживачів та їхню структуру. Виявлено незбалансованість бюджету споживачів, а також недостатність фактичних доходів для забезпечення наявних потреб населення. Проаналізовано показник ВВП та індекси-дефлятори, які $\epsilon$ індикаторами реальної купівельної спроможності споживачів. Розглянуто «індекс щастя» як критерій, який впливає на схильність до споживання та заощадження. Запропоновано кроки, що сприятимуть підвищенню економічної ефективності поведінки спожсивача та максимізації його корисності.

Ключові слова: поведінка споживача, корисність, дохід, витрати, ВВП, дефлятор, потреби, купівельна спроможність.

Табл.: 2. Рис.: 2. Літ.: 16.

\title{
CONSUMER BEHAVIOUR IN THE MODERN MARKET ECONOMY
}

\author{
BROYAKA Antonina, \\ Candidate of Economic Sciences, \\ Associate Professor of the Department of Economics, \\ Vinnytsia National Agrarian University \\ (Vinnytsia)
}




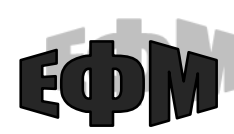

http://efm.vsau.org/

The article investigates the peculiarities of consumer behavior in modern market conditions. The theoretical and methodological approaches to the consumer behavior formation are highlighted; the exogenous and endogenous factors affecting it are identified. The various models of consumer behavior are characterized, depending on their income level. The level and dynamics of income of the population of Ukraine, including in urban and rural areas, are analyzed. The dynamics and cost structure of Ukrainian consumers is investigated. The imbalance of the budget of consumers, as well as the lack of actual income to meet the existing needs of the population, are revealed. The GDP indicator and deflator indices, which are indicators of the real consumer purchasing power, are analyzed. The happiness index is considered as a criterion that affects the propensity to consumption and saving. The measures to increase the economic efficiency of consumer behavior and maximization of its utility are proposed.

Key words: consumer behavior, utility, income, expenses, GDP, deflator, needs, purchasing power.

Tabl.: 2. Fig.: 2. Ref.: 16.

\section{ПОВЕДЕНИЕ ПОТРЕБИТЕЛЯ В СОВРЕМЕННОЙ РЫНОЧНОЙ ЭКОНОМИКЕ}

\section{БРОЯКА Антонина Анатольевна, кандидат экономических наук, доцент, доцент кафедры экономики, \\ Винницкий национальный аграрный университет}

(2. Винница)

В статье исследованы особенности поведения потребителя в современных рыночных условиях. Освещены теоретико-методологические подходы к формированию потребительского поведения и определены влияющие на него экзогенные и эндогенные факторы. Охарактеризованы различные модели поведения потребителей в зависимости от уровня их дохода. Проанализировань уровень и динамика доходов населения Украины, в том числе в городской и сельской местности. Исследована динамика и структура расходов украинских потребителей. Выявлены несбалансированность бюджета потребителей, а также недостаточность фактических доходов для обеспечения существующих потребностей населения. Проанализированы показатель ВВП и индексы-дефляторы, которые являются индикаторами реальной покупательской способности потребителей. Рассмотрен «индекс счастья» как критерий, который влияет на склонность к потреблению и сбережению. Предложено шаги, способствуюшие повышению экономической эффективности поведения потребителя и максимизации её полезности.

Ключевые слова: поведение потребителя, полезность, доход, затраты, ВВП, дефлятор, потребности, покупательная способность.

Табл.: 2. Рис.: 2. Лит.: 16.

Постановка проблеми. Суттєвою ознакою функціонування сучасної ринкової економіки $є$ орієнтир на потреби споживачів. У зв'язку з цим виробники під час формування товарної, цінової, збутової політики повинні чітко розуміти основні закони та тенденції поведінки покупців. Споживач постійно приймає рішення щодо вибору необхідних благ, в основі якого лежить споконвічна економічна суперечність: з одного боку - обмеженість ресурсів особи, яка приймає рішення, з іншого - прагнення максимального задоволення безмежних потреб. Поєднання теорії споживчого вибору із аналізом структури та динаміки попиту, доходів, цін створює більш широку картину цільового ринку, що сприяє формуванню успішної стратегії розвитку підприємств та підвищенню конкурентоспроможності їхньої продукції, розробці й реалізації ефективної державної політики розвитку національної економіки та ії ринків.

Глобалізація економічного простору, безперешкодне пересування товарів, ресурсів (у тому числі фінансових), інформації посилює конкурентну боротьбу виробників за ринки збуту та робить питання дослідження поведінки споживачів все більш актуальним.

Аналіз останніх досліджень та публікацій. Перші спроби створення теорій споживацької поведінки належать видатним вченим світового масштабу, серед яких: Г.Г. Госсен, який досліджував поведінку споживача на основі оцінки ним корисності економічних благ; А. Маршалл, Дж. Фон Непман, О. Моргенштерн - прихильники кардиналістської (кількісної) теорії корисності; Дж. Р. Хікс, П. Самуельсон, які підтримували ординалістську(порядкову) теорію корисності; Ф. Еджворт, який запровадив в економічний аналіз криві байдужості; український економіст Є.Є. Слуцький, який досліджував природу виникнення споживчого надлишку, а також застосував 


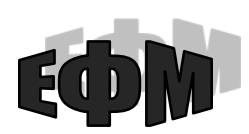

http://efm.vsau.org/

криві байдужості для аналізу залежності споживчого попиту від динаміки цін. Фундаментальні ідеї названих дослідників висвітлено також у працях провідних вітчизняних вчених-економістів: О.Я. Базілінської [1], В.Д. Базилевича, Г.Е. Гронтковської [12], А.Ф. Косік [12], І.О. Луніної, O.I. Ястремського та ін.

Зростання взаємозалежності національних економік, лібералізація торгівельних, міграційних та інформаційних потоків, стрімкий розвиток технологій призводять до виникнення нового типу сучасного споживача, поведінка якого потребує подальшого вивчення. В українській періодиці певні аспекти зміни поведінки споживача в сучасних умовах висвітлено в публікаціях Т.Л. Бондарчук [2], О.В. Василькевич [5], Н.І. Дубинської, Т.Т. Жовковської [9], О.В. Свтушевської [8], Т.В. Овчіннікової, В.М. Торяник [13], Г.О. Шамборського, Л.О. Шкварчук [15] та ін. Однак більшість науковців переважно використовують у своїх дослідженнях маркетинговий підхід і рідше здійснюють економічний аналіз сучасних тенденцій споживацької поведінки населення.

Формулювання цілей статті. Метою статті $\epsilon$ оцінка та інтерпретація 3 погляду мікроекономічних та макроекономічних характеристик поведінки споживача в ринковому середовищі в сучасних умовах.

Виклад основного матеріалу дослідження. Узагальнюючи багаточисленні визначення поняття «поведінка споживача», наведені у працях вітчизняних вчених $[2,5,9]$, можна зробити висновок, що це - процес ухвалення споживчих рішень, спрямованих на задоволення власних потреб шляхом вибору, придбання, споживання товарів та послуг. На формування моделі поведінки конкретного споживача більшою чи меншою мірою впливає низка ендогенних та екзогенних чинників, зокрема:

1. Особистісні (суб'єктивні уподобання, смаки, звички, вік, спосіб життя, рід занять, досвід, освіта, знання);

2. Психологічні (уявлення про себе, мотивація, власні переконання та особисті цінності, сприйняття зовнішнього середовища, емоційність, імпульсивність);

3. Економічні (ринкова ціна, рівень доходів, стабільність економіки, корисність товару чи послуги, еластичність попиту, ставка процента);

4. Соціокультурні (національність, культура, менталітет, суспільні цінності та інтереси, родина, соціальне становище);

5. Політичні (державний устрій, політичний режим, ідеологія, політична ситуація, політична інтегрованість індивіда, зовнішньоекономічна політка держави).

Модель поведінки споживача - це формалізоване описання, концептуальна схема взаємозв'язку між діяльністю людини та мотивом, що ії̈ зумовив [2]. Розглядаючи модель поведінки споживача як процес, можна вважати, що це рух від усвідомлення потреби до реакції покупця на спожитий продукт. Причому кожному типу сучасного споживача притаманна своя модель поведінки на ринку, адже кожен покупець:

a) сам визначає, який товар на його думку має найвищу корисність, враховуючи власну систему оцінки переваг;

б) об'єктивно оцінює свої потреби та матеріальні можливості щодо їх задоволення;

в) є обізнаним щодо цін, торгівельних марок, їхніх відмінностей у якості, додаткових умов, супутніх послуг, акцій тощо.

У контексті економічного підходу до аналізу поведінки суб'єкта споживач розглядається як раціональний індивід, тобто він точно знає, чого він бажає, і його діяльність скерована на максимізацію власної вигоди та покращення свого економічного становища. Визначаючи переваги того чи іншого блага або набору благ, споживач здійснює їх порівняння, ранжування за ступенем привабливості та обирає те, яке йому подобається більше. У випадку ж порівняння наборів благ, споживач зазвичай віддає перевагу тому набору, який містить більшу кількість товарів за ту саму вартість. У науковій літературі зазначені припущення щодо поведінки раціонального споживача відомі як аксіоми уподобань, які лежать в основі ординалістського (порядкового) підходу [1; 12; 13]. Однак такий підхід грунтується переважно на власній системі цінностей споживача $\mathrm{i}$ відокремлений від впливу екзогенних чинників, які в сучасній ринковій економіці мають вагоме значення для прийняття споживачем рішення щодо придбання того чи іншого товару, обсягів закупівлі та структури споживання.

У сучасних умовах основним економічним чинником, що впливає на поведінку споживача та обсяги придбаної продукції, $є$ рівень його доходу [8]. Згідно з класичним розумінням, на обсяг попиту впливає ціна: чим вона вища, тим менший обсяг попиту. Але ще Дж. Кейнс зауважив, що 


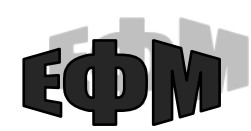

http://efm.vsau.org/

саме дохід $є$ основоположним у формуванні обсягу попиту і ця залежність $є$ прямою: чим більший дохід, тим більшим є обсяг попиту. Він вводить поняття «схильності до споживання», що демонструє, яка частка з кожної одиниці доходу буде спрямована на споживання [13].

У ринковій економіці поведінка споживачів із різним рівнем доходів відрізняється. Споживачі із нижчим рівнем доходу частіше поводяться раціональніше, купують ті товари, що задовольняють нагальні потреби та є більш привабливішими за ціною. Середній клас переважно обирає продукцію за критерієм «ціна-якість». Ступінь раціональності їхньої поведінки буде залежати від стабільності економіки та сподівань споживачів щодо реального майбутнього доходу. Що стосується споживачів із високим рівнем доходів, то їхній попит не залежить від ціни, оскільки вища вартість купленого ними товару підвереджує їхню заможність та статус. Однак така класифікація є узагальненою, оскільки у кожній умовній групі споживачів трапляються винятки: бідніші можуть бути марнотратними аби справляти враження успішності, натомість багатші можуть бути схильні до економії та заощадження.

Завданням економічного оцінювання поведінки споживача $є$ аналіз кількісних та вартісних параметрів прояву відповідних особистісно-психологічних, соціально-економічних та політичних мотивів, які відображаються у рівні доходів та витрат, обсягах та структурі споживання, величині заощаджень, індексі щастя та інших показниках [7; 15]. Проаналізуємо деякі з них у нашій державі.

Розподіл доходів населення України за рівнем середньодушових еквівалентних загальних доходів за останні 3 роки наведено у таблиці 1, дані якої свідчать про зростання частки населення, що має вищі доходи (для порівняння, у 2018 році 27,4\% українців мало доходи понад 5160 грн проти $12,6 \%$ у 2017 році), причому така тенденція спостерігається як у містах (30,5\% у 2018 році порівняно із 13,6\% у 2017 році), так і в сільській місцевості (21,2\% у 2018 році порівняно із 10,4\% у 2017 році). Однак сільські мешканці переважно мають нижчі загальні доходи порівняно із містянами: у 2016 році за даними обстежень Державної служби статистки України міське домогосподарство отримувало у середньому за місяць 5842 грн (в розрахунку на 1 особу 2809 грн), сільське - 5871 грн (в розрахунку на 1 особу 2706 грн); у 2017 році - відповідно 7749 грн (в розрахунку на 1 особу 3725 грн) та 7542 грн (в розрахунку на 1 особу 3476 грн); у 2018 році відповідно 9722,5 грн та 9073,3 грн. Зростання доходів зумовлене підвищенням мінімального та середнього рівня заробітних плат, обсягу трансфертних платежів (зокрема, субсидій та інших видів соціальної допомоги), доходів від підприємницької діяльності тощо. Значну частину у доходах населення України займає заробітна плата, яка зросла із 40,8\% у 2010 році до 45,6\% у 2017 році.

Проте не варто забувати, що це констатація зростання номінальних доходів, яких в умовах стрімкого підвищення цін недостатньо, аби задовольнити навіть базові потреби споживачів. Більшість населення України знаходяться на межі виживання, «від зарплати до зарплати». Так у 2018 році частка населення із середньодушовими еквівалентними загальними доходами у місяць, нижчими за середній рівень в Україні становила $60 \%$, нижчими за фактичний прожитковий мінімум (3236,52 грн) - 29,3\%, нижчими за законодавчо встановлений прожитковий мінімум (1725,67 грн) - 1,7\%. При цьому необхідно звернути увагу на те, що фактичний прожитковий мінімум майже вдвічі більший, ніж законодавчо затверджений прожитковий мінімум, що штучно зменшує рівень усіх соціальних і пенсійних виплат, які на ньому базуються, і як наслідок значно знижує купівельну спроможність споживачів [10]. У 2014 році частка населення із середньодушовими еквівалентними загальними доходами у місяць, нижчими від фактичного прожиткового мінімуму, становила 16,7\%, а в наступному - 2015 році - 52,9\%, що було пов'язано із значним стрибком рівня інфляції, який становив $43,3 \%$.

Аналізуючи дані табл. 1, можна зробити висновок, що незважаючи на фактичне підвищення доходів, купівельна спроможність споживачів України є достатньо низькою, що спричинено зменшенням реальних доходів населення.

Поведінка споживача значною мірою зумовлюється купівельною спроможністю його доходу, тобто здатністю в певній пропорції обмінюватися на необхідні товари та послуги. Купівельну спроможність споживачів можна оцінити за обсягом продукції, яку вони отримують за свої наявні доход, а також за структурою споживаного набору товарів та послуг.

Як свідчить рис. 1, розрив між доходами населення та його витратами на закупівлю товарів $\mathrm{i}$ послуг доволі малий, тобто майже всі свої грошові ресурси українці витрачають на поточне споживання, а отже можливість нагромадження заощаджень низька, що відповідно скорочує перспективу зростання попиту на більш дорогі товари, в тому числі тривалого користування, подорожі, нерухомість тощо. Найнижчий рівень частки витрат населення на придбання товарів і 
http://efm.vsau.org/

послуг у річному доході у період 2005-2017 років був у 2010 році - 76\%, а найвищий у 2017 році 89\%. За попередніми підсумками 2018 року, частка витрат українців у їхньому доході в середньому знаходиться межах $85 \%$.

Важливість дослідження особливостей поведінки споживача в Україні доводиться тим фактом, що у структурі ВВП споживання домашніх господарств $є$ основним елементом. Як свідчать дані таблиці 2, частка кінцевих споживчих витрат домогосподарств у ВВП зростає і у 2018 році становила $68,3 \%$ від фактичного ВВП, що на 5,3\% більше, ніж у 2010 році.

Таблиия 1

Розподіл населення Украӥни за рівнем середньодушових еквівалентних загальних доходів у 2016-2018 роках, \%

\begin{tabular}{|c|c|c|c|c|c|c|c|c|c|}
\hline \multirow[b]{3}{*}{ Показники } & \multicolumn{3}{|c|}{9 місяців $2016 \mathrm{p}$. } & \multicolumn{3}{|c|}{9 місяців $2017 \mathrm{p}$. } & \multicolumn{3}{|c|}{9 місяців $2018 \mathrm{p}$. } \\
\hline & \multirow{2}{*}{ 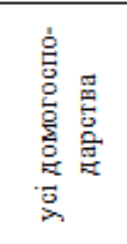 } & \multicolumn{2}{|c|}{$\begin{array}{c}\text { у т.ч. } \\
\text { прожпвакоть }\end{array}$} & \multirow{2}{*}{ 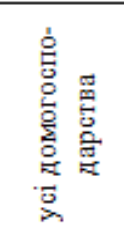 } & \multicolumn{2}{|c|}{$\begin{array}{c}\text { у т.ч. } \\
\text { проживають }\end{array}$} & \multirow{2}{*}{ 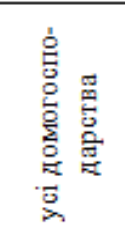 } & \multicolumn{2}{|c|}{$\begin{array}{c}\text { ут.ч. } \\
\text { проживають }\end{array}$} \\
\hline & & 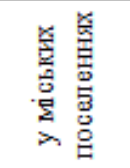 & 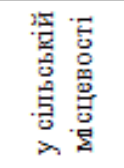 & & 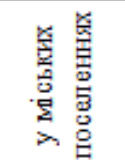 & 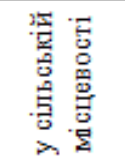 & & 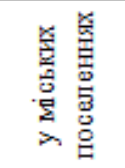 & 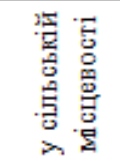 \\
\hline Усе населення (тис.) & 38841,9 & 25671,7 & 13170,2 & 386979 & 255998 & 13098,1 & 38549,7 & 25528,7 & 13021,0 \\
\hline \multicolumn{10}{|c|}{ Із середньодушовим еквівалентними загальними доходами у місяць, грн: } \\
\hline до 1920,0 & 23,0 & 23,5 & 22,6 & 8,7 & 8,0 & 10,1 & 3,0 & 2,7 & 3,7 \\
\hline $1920,1-2280,0$ & 16,2 & 15,7 & 17,2 & 8,7 & 8,4 & 9,6 & 5,0 & 4,2 & 6,8 \\
\hline $2280,1-2640,0$ & 16,2 & 16,8 & 15,0 & 12,1 & 12,3 & 11,8 & 6,7 & 6,6 & 6,9 \\
\hline $2640,1-3000,0$ & 12,4 & 11,3 & 14,5 & 11,4 & 11,6 & 11,2 & 8,7 & 8,3 & 9,6 \\
\hline $3000,1-3360,0$ & 9,6 & 9,7 & 8,8 & 11,5 & 11,6 & 11,4 & 8,9 & 8,9 & 8,8 \\
\hline $3360,1-3720,0$ & 7,1 & 7,1 & 7,2 & 10,9 & 10,6 & 11,4 & 9,1 & 9,3 & 8,8 \\
\hline $3720,1-4080,0^{3}$ & 15,5 & 15,9 & 14,7 & 7,5 & 7,0 & 8,4 & 9,3 & 9,2 & 9,7 \\
\hline $4080,1-4440,0$ & $\ldots$ & $\ldots$ & $\ldots$ & 6,8 & 6,6 & 7,1 & 7,7 & 6,9 & 8,8 \\
\hline $4440,1-4800,0$ & $\ldots$ & $\ldots$ & $\ldots$ & 5,6 & 6,0 & 4,7 & 7,5 & 7,0 & 8,4 \\
\hline $4800,1-5160,0$ & $\ldots$ & $\ldots$ & $\ldots$ & 4,2 & 4,3 & 3,9 & 6,7 & 6,4 & 7,3 \\
\hline понад 5160,0 & $\ldots$ & $\ldots$ & $\ldots$ & 12,6 & 13,6 & 10,4 & 27,4 & 30,5 & 21,2 \\
\hline \multicolumn{10}{|c|}{ Частка населеннл із середньодушовими еквівалентними загальними доходами у місяць, нижчими: } \\
\hline $\begin{array}{l}\text { - середнього рівня } \\
\text { загальних доходів }\end{array}$ & 61,0 & 62,2 & 58,8 & 60,9 & 62,5 & 56,5 & 60,0 & 60,7 & 57,5 \\
\hline $\begin{array}{l}\text { - законодавчо } \\
\text { встановленого } \\
\text { прожикового } \\
\text { мінімуму }\end{array}$ & 4,8 & 4,7 & 5,1 & 3,3 & 2,5 & 4,6 & 1,7 & 1,3 & 2,4 \\
\hline $\begin{array}{l}\text { - фактинного } \\
\text { прожиткового } \\
\text { мінімуму }\end{array}$ & 53,6 & 54,1 & 52,6 & 38,2 & 37,7 & 39,3 & 29,3 & 27,6 & 32,6 \\
\hline
\end{tabular}

Джерело: сформовано автором за даними Держсвної служби статистики Украӥни [6]

Споживання є найдинамічнішою складовою ВВП, темп його зміни переважно більший, порівняно із темпом зміни ВВП, і це стосується не тільки зростання, а й скорочення. Якщо у 2014 та 2015 роках відбулося зменшення фізичного обсягу ВВП (на 6,6\% та 3,2\% відповідно до попереднього року), то й споживання скоротилося, але значно вищими темпами (на $15,2 \%$ та 11,5\%). 3 економічного погляду така взаємозалежність $€$ проявом мультиплікативного ефекту зміни витрат та доходів. 3 психологічного ж - економічна криза, зумовлена нестабільною військовополітичною ситуацією в Україні, змушує споживача поводитися більш раціонально, скорочує марнотратство, збільшує схильність до заощадження.

Зміну реального ВВП, а отже й реальної купівельної спроможності споживачів, можна прослідкувати за допомогою дефлятора. Індекси-дефлятори - це сукупність індексів цін, які надають узагальнену характеристику їх змін у звітному періоді порівняно 3 цінами періоду, прийнятого за базовий [4]. Ціни 3 року в рік змінюються, як наслідок змінюються і потреби споживачів залежно від зміни їхніх реальних доходів [14]. Аналіз індексів свідчить, що криза 20082009 років фактично зруйнувала купівельну спроможність українців і у наступну кризу країна увійшла у вкрай послабленому стані, так і не встигнувши іiі відновити. 2014-2015 роки характеризуються різким падінням ВВП, стрімким підвищенням цін та зниженням рівня життя населення [3]. 


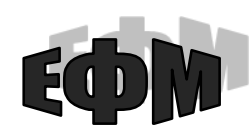

http://efm.vsau.org/

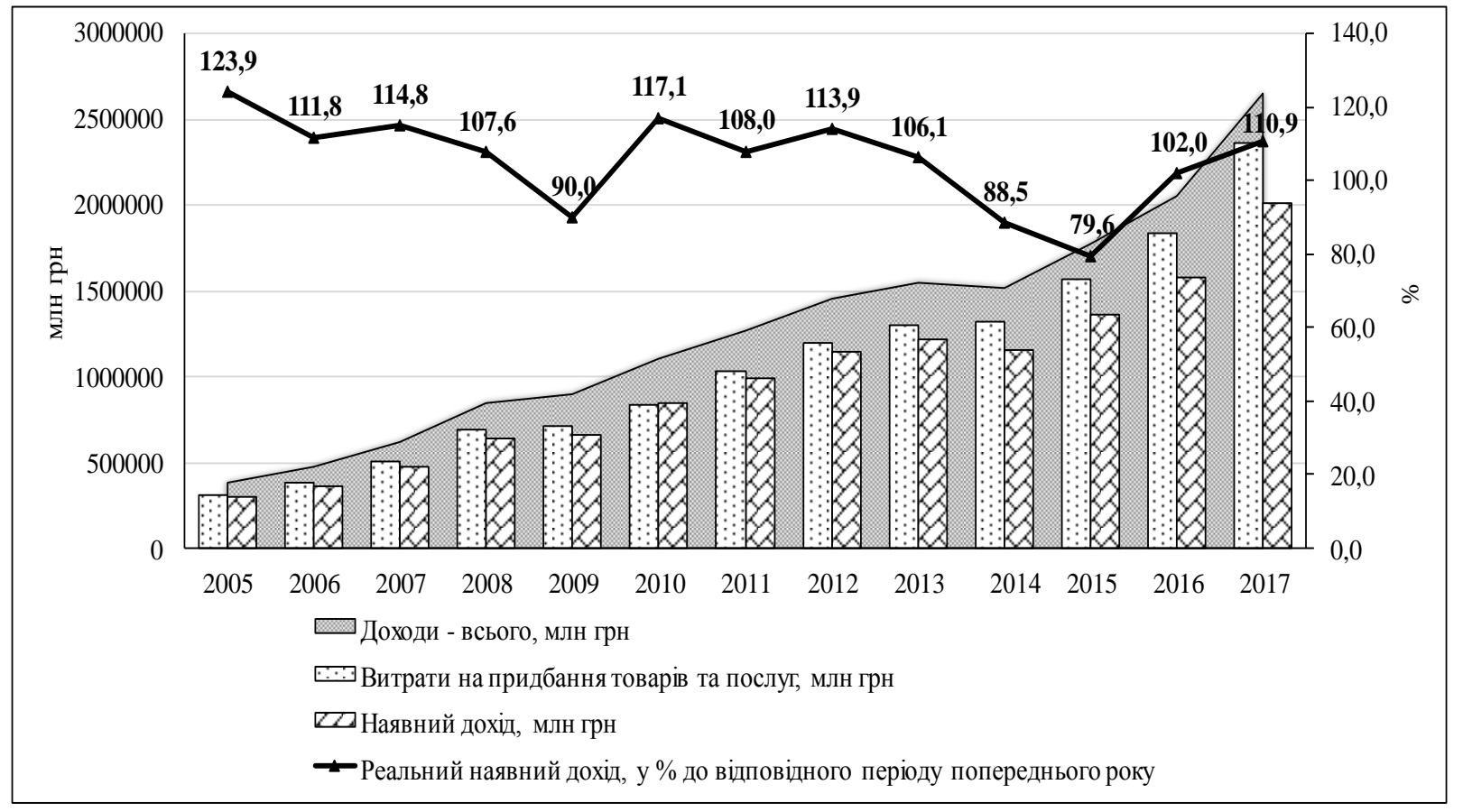

Рис. 1. Доходи та витрати населення України у 2005-2017 роках

Джерело: сформовано автором за даними Державної служби статистики Украӥни [6]

Порівнюючи зміну дефлятора ВВП та зміну дефлятора споживання (табл. 2), бачимо, що їхня динаміка у 2010-2014 роках мала подібну тенденцію, а починаючи з переламного 2016 року, який характеризується зростанням фізичного ВВП, споживачі поводяться більш стримано щодо купівель, навіть при уповільненні темпів приросту інфляції та поступових ознаках подолання негативних наслідків кризи. Причиною такої поведінки споживачів $є$ песимістичні очікування щодо майбутньої економічної ситуації в країні, скорочення попередньо накопичених заощаджень, зростання рівня бідності населення.

Таблиия 2

Динаміка ВВП та споживчих витрат домашніх господарств України у 2010-2018 роках

\begin{tabular}{|c|c|c|c|c|c|c|c|}
\hline $\begin{array}{l}5 \\
0 \\
0 \\
0\end{array}$ & 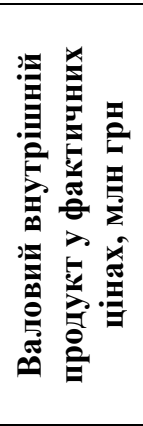 & 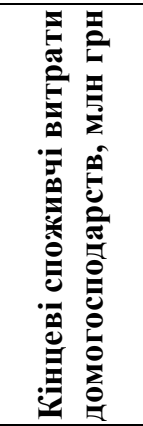 & 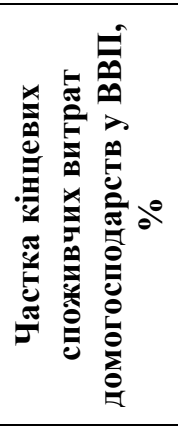 & 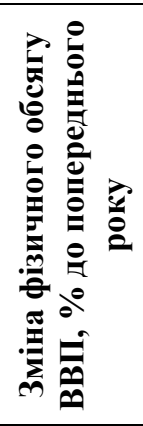 & 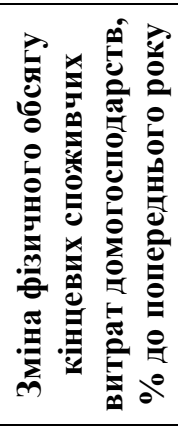 & 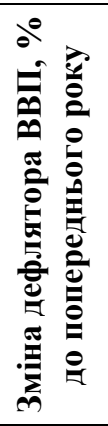 & 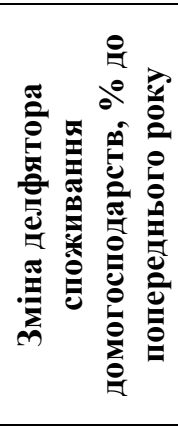 \\
\hline 2010 & 1079346 & 680164 & 63,0 & 104,1 & 107,0 & 113,7 & 110,1 \\
\hline 2011 & 1299991 & 858905 & 66,1 & 105,5 & 115,7 & 114,2 & 109,1 \\
\hline 2012 & 1404669 & 950212 & 67,7 & 100,2 & 108,4 & 107,8 & 102,1 \\
\hline 2013 & 1465198 & 1047096 & 71,4 & 100,0 & 106,9 & 104,3 & 103,1 \\
\hline 2014 & 1586915 & 1120876 & 70,6 & 93,4 & 91,7 & 115,9 & 116,7 \\
\hline 2015 & 1988544 & 1331526 & 67,0 & 90,2 & 80,2 & 138,9 & 148,2 \\
\hline 2016 & 2385367 & 1569702 & 65,8 & 102,4 & 102,7 & 117,1 & 114,8 \\
\hline 2017 & 2983882 & 1977640 & 66,3 & 102,5 & 109,5 & 122,1 & 115,0 \\
\hline 2018 & 3558706 & 2431014 & 68,3 & 103,3 & 108,9 & 115,4 & 112,9 \\
\hline
\end{tabular}

Економічне оцінювання поведінки споживачів доцільно здійснювати за окремим товарними групами. Продовольчі товари - найважливіша складова витрат споживачів, оскілки вони задовольняють першочергові фізіологічні потреби і $\epsilon$ слабоеластичними відносно цінових коливань. Споживачі витрачають на них більшу половину свого доходу (рис. 2), що зумовлено 
низьким рівнем заробітних плат більшості працівників, високим рівнем безробіття та неповною зайнятістю, диспаритетом нинішніх цін та реальних доходів населення. Для порівняння: в економіці розвинених країн на харчування витрачається в середньому до $20 \%$ усіх доходів, а за умов, коли частка продуктів харчування становить 50-60\% ресурсів населення, країна вважається бідною і більша частка населення є малозабезпеченою [11].

Протягом останніх років спостерігаються певні зміни в структурі середньомісячних споживчих витрат населення України на закупівлю товарів та послуг. В основному ці зміни зумовлені зростанням частки витрат домогосподарств на утримання житла (включаючи поточний ремонт), воду, електроенергію, газ та інші види палива з 10,26\% у 2010 році до 18,3\% у 2017 році. Значні масштаби низькодохідності є основною причиною незбалансованого споживчого бюджету родини та деприваційної бідності українських споживачів. Рівень бідності за ознаками депривації - вимушеного позбавлення особи внаслідок нестачі коштів можливості задовольняти свої базові потреби через відсутність доступу до основних матеріальних благ і соціальних ресурсів, у 2017 році був найбільшим за період 2007-2017 років (за чотирма 318 ознак позбавлень) [10]. Приблизно 6\% доходу споживачі втрачають на закупівлю одягу та взуття (при цьому 27,5\% населення мають недостатньо коштів для оновлення верхнього одягу та взуття для холодної пори року один раз на 5 років). В середньому лише $4 \%$ свого бюджету споживачі витрачають на охорону здоров'я, і це не тому, що медичні послуги «безкоштовні», а тому що 31,7 \% населення не має достатньо коштів для закупівлі призначених ліків і медичного приладдя.

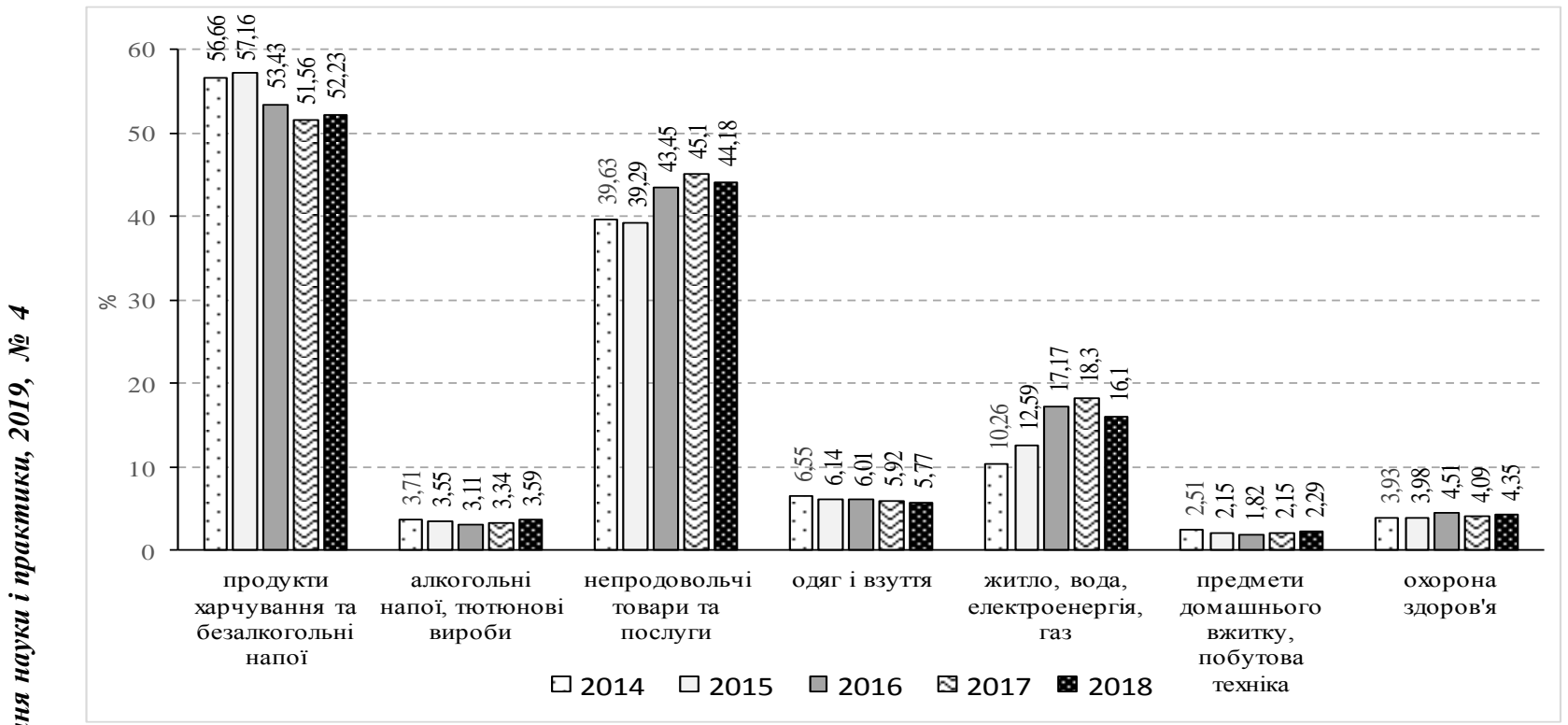

Рис. 2. Динаміка структури витрат споживачів у середньому за місяць у розрахунку на одне домогосподарство в Україні у 2014-2018 роках

Джерело: сформовано автором за даними Державної служби статистики Украйни [6]

Незбалансованість ресурсів та витрат споживачів, диспаритет цін та доходів, недоступність належного харчування, якісного медичного обслуговування, низький рівень ВВП у розрахунку на душу населення, високий рівень безробіття посилюють негативний вплив психологічних та економічних чинників на раціональну поведінку споживача, яка залежить від ступеня відчуття ним благополуччя. Виміряти його достатньо складно, однак найбільш об'єктивним показником вважається «індекс щастя», який інтегрує у собі ряд окремих індикаторів [7]. Аналізуючи рейтинг країн світу за «індексом щастя», варто зазначити, що у 2018 році Україна посіла 138 місце зі 156 країн, опустившись на 6 сходинок, порівняно з попереднім роком. Причому, як зазначено у звіті «World Happiness Report 2018», це одне з п'яти наймасштабніших знижень рівня щастя у зв'язку 3 економічними, політичними та соціальними стресами з 2008-2010 років (поряд із Сменом, Сирією, Малаві та Венесуелою) [16]. Звісно, що сьогоденна незадоволеність життям все більше знижує схильність до споживання в майбутньому.

Висновки. Отже, найбільший вплив на поведінку споживача чинить його реальний дохід. Оскільки наразі частка споживчих витрат є домінантною, практично не формуються заощадження та потенціал для економічного зростання. В умовах недостатньої фінансово-матеріальної забезпеченості населення України важливим кроком держави для підтримання купівельної спроможності споживачів є субсидіювання комунальних послуг, надання пільг та дотацій на 


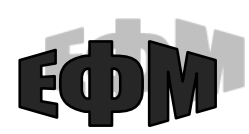

http://efm.vsau.org/

отримання послуг з охорони здоров'я, проїзду у транспорті, відпочинку, громадського харчування тощо. Проте такий інструмент не дасть очікуваних результатів без комплексної терапії економіки країни. Необхідно здійснити реформування системи оплати праці, зокрема відпрацювати організаційно-економічний механізм легалізації тіньової заробітної плати, стягнення 3 неї відповідних соціальних внесків та податків; удосконалити методику встановлення прожиткового мінімуму та привести його у відповідність до реальних потреб споживача; систематично здійснювати належну індексацію доходів, особливо в приватному бізнесі; збільшувати цільові інвестиції у розширення капіталу реального сектору економіки, що одночасно збільшить кількість робочих місць, ВВП та доходи населення; відновити регулювання цін на товари першої необхідності та багато інших заходів. Однак найголовніше завдання - це мир в країні, подолання корупції, підвищення соціально-економічних стандартів, стабілізація економічної ситуації, $\mathrm{i}$, як наслідок, відродження оптимістичного настрою суспільства. Тільки за таких умов споживач може максимізувати свою корисність, раціонально використовуючи свій наявний дохід.

\section{Список використаних джерел}

1. Базілінська О.Я. Мікроекономіка: теорія та практика. Київ: Києво-Могилянська академія, 2007. $272 \mathrm{c}$.

2. Бондарчук Т.В. Модель поведінки споживача: теоретико-методологічні аспекти. Глобальні та національні проблеми економіки. Вип. 11. 2016. С. 3-7.

3. Брояка А. А. Аналіз основних макроекономічних індикаторів соціально-економічного розвитку України. Проблеми економіки. 2018. №1. С. 42-48.

4. Валовий внутрішній продукт у 2010-2018 рр. Київ: Офіс з фінансового та економічного аналізу у Верховній Раді України, 2018. 27 с. [Електронний ресурс]. Режим доступу: https://feao.org.ua/wp-content/uploads/2018/10/gdp2010-2018-1.pdf.

5. Василькевич О.В. Соціально-економічна природа поведінки споживачів на ринку товарів та послуг. Ефективна економіка. 2011. №7 [Електронний ресурс]. Режим доступу: http://www.economy.nayka.com.ua/?op=1\&z=621.

6. Державна служба статистики України [Електронний ресурс]. Режим доступу: http://www.ukrstat.gov.ua/.

7. Дикань В.Л., Воловельская И.В. Особенности поведения потребителей в условиях "экономики счастья". Вісник економіки транспорту і промисловості. 2017. № 60. С. 11-17.

8. Свтушевська О.В. Особливості поведінки споживачів на ринку в сучасних умовах. Інвестиції: практика та досвід. 2016. №20. С. 22-24.

9. Жовковська Т. Формування моделі поведінки споживача. Економічний дискурс. 2017. Вип. 2. С. 9-18.

10.Звіт про результати аналізу виконання заходів з реалізації стратегії подолання бідності. К: Розрахункова палата, 2018. 94 с. Електронний ресурс]. Режим доступу: http://www.acrada.gov.ua/doccatalog/document/16757712/Zvit_23-3_2018.pdf.

11.Калетнік Г.М., Коваленко О.В., Брояка А.А. Сучасні тенденції розвитку харчової промисловості та їі місце в економіці держави. Економіка, фінанси, менеджмент: актуальні питання науки та практики . 2017. №8 (36). С. 7-26.

12.Косік А.Ф., Гронтковська Г.Е. Мікроекономіка. Київ: ЦУЛ, 2008. 438 с.

13.Торяник В.М. Теорія споживчої поведінки як предтеча концепції політичного консумеризму. Політологічні записки. 2011. № 4 [Електронний ресурс]. Режим доступу: http://nbuv.gov.ua/UJRN/Polzap_2011_4_53.

14.Хаєцька О.П. Основні макроекономічні показники та їх вплив на зростання добробуту населення України. Сучасний стан та перспективи розвитку економіки, обліку, менеджменту, фінансів та права: збірник тез доповідей міжнародної науково-практичної конференції (26 січня 2019 р.). Полтава: ЦФЕНД, 2019. Ч.2. С. 53-55.

15.Шкварчук Л.О. Сучасні тенденції поведінки населення. Вісник Національного університету "Львівська політехніка". Логістика. 2015. № 833. С. 124-130.

16.World Happiness Report 2018. [Електронний ресурс]. Режим доступу: http://worldhappiness.report/ed/2018/.

\section{References}

1. Bazilinska O.Ia. (2007). Mikroekonomika: teoriia ta praktyka [Microeconomics: theory and practice]. Kyiv, Kyievo-Mohylianska akademiia - Kyiv Mohyla Academy, 272 p. [in Ukrainian].

2. Bondarchuk T.V. (2016). Model povedinky spozhyvacha: teoretyko-metodolohichni aspekty [Consumer behavior model: theoretical and methodological aspects]. Hlobalni ta natsionalni problemy ekonomiky - Global and national problems of the economics, Vol. 11, pp. 3-7 [in Ukrainian]. 


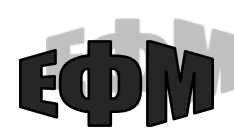

http://efm.vsau.org/

3. Broyaka A.A. (2018). Analiz osnovnykh makroekonomichnykh indykatoriv sotsialno-ekonomichnoho rozvytku Ukrainy [Analysis of the Main Macroeconomic Indicators of the Socio-Economic Development of Ukraine]. Problemy ekonomiky - The Problems of the Economy, No.1, pp. $42-48$ [in Ukrainian].

4. Valovyi vnutrishnii produkt u 2010-2018 rr. [Gross Domestic Product in 2010-2018] (2018). Kyiv, Ofis z finansovoho ta ekonomichnoho analizu u Verkhovnii Radi Ukrainy - Financial and Economic Analysis Office in the Verkhovna Rada of Ukraine. 27 p. Retrieved from: https://feao.org.ua/wpcontent/uploads/2018/10/gdp2010-2018-1.pdf [in Ukrainian].

5. Vasylkevych O.V. (2011). Sotsialno-ekonomichna pryroda povedinky spozhyvachiv na rynku tovariv ta posluh [Socio-economic nature of consumer's behavior on the market of goods and services]. Efektyvna ekonomika - Effective economy, No. 7. Retrieved from: http://www.economy. nayka.com.ua/?op=1\&z=621 [in Ukrainian].

6. Derzhavna sluzhba statystyky Ukrayiny [Official site of the State Statistics Service of Ukraine]. Retrieved from: http://www.ukrstat.gov.ua/ [in Ukrainian].

7. Dykan V.L. Volovelskaya I.V. (2017). Osobennosti povedeniya potrebiteley v usloviyakh "ekonomiki schastia" [Features of consumer behavior in terms of the "economics of happiness"]. Visnyk ekonomiky transportu i promyslovosti - The Bulletin of Transport and Industry Economics, No. 60, pp. 11-17 [in Russian].

8. Yevtushevska O.V. (2016). Osoblyvosti povedinky spozhyvachiv na rynku v suchasnykh umovakh [Peculiarities of consumers' behavior on market under modern conditions]. Investytsii: praktyka ta dosvid - Investments: practice and experience, No. 20, pp. 22-24 [in Ukrainian].

9. Zhovkovska T. (2017). Formuvannia modeli povedinky spozhyvacha [Forming the model of consumer behavior]. Ekonomichnyi dyskurs - The Economic Discourse, Issue 2, pp. 9-18 [in Ukrainian].

10. Zvit pro rezultaty analizu vykonannia zakhodiv z realizatsii stratehii podolannia bidnosti [Report on the results of the analysis of the implementation of measures to implement the poverty reduction strategy] (2018). Kyiv, Rozrakhunkova palata - Court of Accounts, 94 p. Retrieved from: http://www.acrada.gov.ua/doccatalog/document/16757712/Zvit_23-3_2018.pdf [in Ukrainian].

11. Kaletnik H.M., Kovalenko O.V., Broyaka A.A. (2017). Suchasni tendentsii rozvytku kharchovoi promyslovosti ta yii mistse v ekonomitsi derzhavy [Current trends of development of the food industry and its place in the state economy]. Ekonomika, finansy, menedzhment: aktualni pytannia nauky ta praktyky - Economy, finances, management: topical issues of science and practical activity, No. 8 (36), pp. 7-26 [in Ukrainian]. uchbovoi literatury, 438 p. [in Ukrainian].

12. Kosik A.F., Hrontkovska H.E. (2008). Mikroekonomika [Microeconomics]. Kyiv, Tsentr

13. Torianyk V.M. (2011). Teoriia spozhyvchoi povedinky yak predtecha kontseptsii politychnoho konsumeryzmu [The theory of consumer behavior as a forerunner of the concept of political consensus]. Politolohichni zapysky - Political notes, No. 4. Retrieved from: http://nbuv.gov.ua/ UJRN/Polzap_2011_4_53 [in Ukrainian].

14. Khaietska O.P. (2019). Osnovni makroekonomichni pokaznyky ta yikh vplyv na zrostannia dobrobutu naselennia Ukrainy [The main macroeconomic indicators and their impact on the welfare of Ukrainian population]. Suchasnyi stan ta perspektyvy rozvytku ekonomiky, obliku, menedzhmentu, finansiv ta prava: zbirnyk tez dopovidei mizhnarodnoi naukovo-praktychnoi konferentsii (26 sichnia 2019 r.) Current state and prospects for the development of economy, accounting, management, finance and law: a collection of abstracts of international scientific and practical conference (January 26, 2019). Poltava, Tsentr finansovo-ekonomichnykh doslidzhen, Part 2, pp. 53-55 [in Ukrainian].

15. Shkvarchuk L.O. (2015). Suchasni tendentsii povedinky naselennia [Modern trends in consumer behavior of the population]. Visnyk Natsionalnoho universytetu "Lvivska politekhnika". Lohistyka - Bulletin of Lviv Polytechnic National University. Logistics, No. 833, pp. 124-130 [in Ukrainian].

16. World Happiness Report 2018. (2018). Retrieved from: http://worldhappiness.report/ed/2018/.

\section{Інформація про автора}

БРОЯКА Антоніна Анатоліївна - кандидат економічних наук, доцент кафедри економіки, Вінницький національний аграрний університет (21008, м. Вінниця, вул. Сонячна, 3, e-mail: broyaka@vsau.vin.ua).

BROYAKA Antonina - Candidate of Economic Sciences, Associate Professor of the Department of Economics, Vinnytsia National Agrarian University (3 Soniachna Str., Vinnytsia, 21008, e-mail: broyaka@vsau.vin.ua).

БРОЯКА Антонина Анатольевна - кандидат экономических наук, доцент кафедры экономики, Винницкий национальный аграрный университет $(21008$, г. Винница, ул. Солнечная, 3 , e-mail: broyaka@vsau). 